\title{
Heavy Metals Assimilation by Native and Non-Native Aquatic Macrophyte Species: A Case Study of a River in the Eastern Cape Province of South Africa
}

\author{
Getrude Tshithukhe *, Samuel N. Motitsoe (D) and Martin P. Hill \\ Centre for Biological Control, Department of Zoology and Entomology, Rhodes University, P.O. Box 94, \\ Makhanda 6140, South Africa; s.motitsoe@ru.ac.za (S.N.M.); m.hill@ru.ac.za (M.P.H.) \\ * Correspondence: get.tshithukhe@gmail.com
}

Citation: Tshithukhe, G.; Motitsoe, S.N.; Hill, M.P. Heavy Metals Assimilation by Native and Non-Native Aquatic Macrophyte Species: A Case Study of a River in the Eastern Cape Province of South Africa. Plants 2021, 10, 2676. https://doi.org/10.3390/ plants10122676

Academic Editors: Cinzia Forni,

Maria Luce Bartucca and

Martina Cerri

Received: 19 October 2021

Accepted: 19 November 2021

Published: 6 December 2021

Publisher's Note: MDPI stays neutral with regard to jurisdictional claims in published maps and institutional affiliations.

Copyright: (C) 2021 by the authors. Licensee MDPI, Basel, Switzerland. This article is an open access article distributed under the terms and conditions of the Creative Commons Attribution (CC BY) license (https:/ / creativecommons.org/licenses/by/ $4.0 /)$.

\begin{abstract}
There is continuous deterioration of freshwater systems globally due to excessive anthropogenic inputs, which severely affect important socio-economic and ecological services. We investigated the water and sediment quality at 10 sites along the severely modified Swartkops River system in the Eastern Cape Province of South Africa and then quantified the phytoremediation potential by native and non-native macrophyte species over a period of 6 months. We hypothesized that the presence of semi and permanent native and non-native macrophytes mats would reduce water and sediment contamination through assimilation downriver. Our results were variable and, thus, inconsistent with our hypotheses; there were no clear trends in water and sediment quality improvement along the Swartkops River. Although variable, the free-floating non-native macrophyte, Pontederia (=Eichhornia) crassipes recorded the highest assimilation potential of heavy metals in water (e.g., Fe and $\mathrm{Cu}$ ) and sediments (e.g., Fe and $\mathrm{Zn}$ ), followed by a submerged native macrophyte, Stuckenia pectinatus, and three native emergent species, Typha capensis, Cyperus sexangularis, and Phragmites australis. Pollution indices clearly showed the promising assimilation by native and non-native macrophytes species; however, the Swartkops River was heavily influenced by multiple non-point sources along the system, compromising the assimilation effect. Furthermore, we emphasise that excessive anthropogenic inputs compromise the system's ability to assimilate heavy metals inputs leading to water quality deterioration.
\end{abstract}

Keywords: bio-concentration factor; enrichment factor; geo-accumulation index; metal contamination; phytoremediation; water quality

\section{Introduction}

Aquatic ecosystems have been subjected to organic and inorganic pollution, which have worsened with poor waste water management [1]. These impacts have resulted in a noticeable loss of aquatic biodiversity, water quality deterioration, ecosystem integrity, and important socio-economic services [2]. Therefore, effective rehabilitation practices and conservation strategies are needed to minimize and control freshwater contamination.

Previous field and mesocosm trials have shown that reversing the impact of anthropogenic inputs in the environment is challenging, and that minimising the level of these inputs and waste management will help curb environmental contamination [3]. Ecologists have tested different methods to try and reduce contamination in freshwater systems, and these include adsorption, soil washing, reverse osmosis, coagulation, and flocculation [4-6].

However, Hanif et al. [7] showed that these methods were costly, sometimes ineffective, and disruptive; for example, soil washing alters sediment microbial communities making it difficult to re-use the treated soil [8]. Methods, such as ion-exchange and artificial membranes, generate end-waste material that requires special deposition, thus, creating additional costs for their disposal [9], whilst coagulation and flocculation can be ineffective in decolorizing laundry effluents [10]. 
It is clear that there is a need for innovative techniques with merits over traditional methods. Green technology, such as phytoremediation, which uses plants and associated microbes to assimilate and breakdown contaminants in natural environments, is one method that has been widely researched and applied [2,11-16]. Phytoremediation is the most innovative, cost-effective, and environmentally friendly technology available to assimilate organic and inorganic contaminants even at low concentrations $[12,17,18]$. Studies have shown that phytoremediation has socio-economic and environmental merits over traditional physicochemical clean-up, and can reduce water quality contamination by more than $50 \%$ in mesocosm settings [19-24].

The assimilation efficacy of macrophytes has been studied by several researchers [9,25-31]. These studies investigated the fate of toxic and non-toxic elements in the field and laboratory using native and non-native macrophytes, and each case study showed improved water chemistry, through reduced nutrients, and heavy metal concentrations after assimilation. To date, phytoremediation feasibility studies have focused on the treatment of heavy-metal contamination when using macrophytes species, such as Typha capensis (Rohrb.) N.E.Br. (Typhaceae) (Bulrush), Phragmites australis (Cav.) Trin. ex Steud (Poaceae) (Common reed), and Cyperus sexagularis (L.) (Cyperaceae) (Swamp flat-sedge) [32-35]. These macrophytes species are widespread and abundant in freshwater systems, they can tolerate different environmental constraints, thus, making them significant candidates for phytoremediation [30]. Furthermore, these macrophytes provide basic ecosystem services that serve an important role in biogeochemical processes, the natural cycling of nutrients [36], and supplying the system with a continuous source of energy [37].

Similarly, non-native macrophytes, including Salvinia molesta D.S. Mitchell (Salviniaceae) (Giant Salvinia), Pistia stratiotes L. (Araceae) (Water lettuce), and Pontederia crassipes (Mart.) Solms-Laub. (Pontederiaceae) (Water hyacinth), have shown to be excellent bioaccumulators $[17,31,38,39]$. These non-native macrophytes species are natural hyperaccumulators and can be effective in assimilating pollutants more than native macrophytes in their introduced range [12,40,41]. Their fibrous root systems, high biomass production rates, and tolerances to disturbed and heavily polluted systems justify their use in treating wastewater, and improving the water quality by assimilating different metals, such as Zinc ( $\mathrm{Zn})$, Arsenic (As), Lead (Pb), Chromium (Cr), and Manganese (Mn) (as seen in Ali et al. [12]).

The selection of plant species for phytoremediation is usually based on their tolerance and ability to accumulate a wide range of contaminants [42]. Non-native macrophytes thrive extremely well in phosphate and nitrate enriched waters as compared to native macrophytes in South Africa [43]; however, such conditions promote high biomass of non-native macrophyte species, such as S. molesta, P. stratiotes, and P. crassipes, making them more effective accumulators, but more also invasive, and thus displacing native aquatic biodiversity $[42,44]$.

Secondly, although non-native macrophyte species have proven to be better assimilators of heavy metals $[16,40,41]$. Non-native macrophytes are equally destructive they modify invaded ecosystems by altering the hydrology and aquatic species composition, reduce ecosystem processes, production, and contribute to lose of aquatic biodiversity $[1,16,45,46]$. Therefore, in this study, we field test the assimilation potential of both native and non-native macrophyte stands found along the Swartkops River in South Africa. We hypothesize that the presence of native and non-native macrophytes species will help reduce the heavy metal contamination in water and sediments downstream of semi and permanent native and non-native stands.

\section{Materials and Methods}

Study Area

The study was conducted in the Swartkops River $\left(33^{\circ} 45^{\prime} 08.0^{\prime \prime} \mathrm{S} 25^{\circ} 20^{\prime} 33.1^{\prime \prime} \mathrm{E}\right.$ to $33^{\circ} 48^{\prime} 37.50^{\prime \prime}$ S $25^{\circ} 30^{\prime} 46.80^{\prime \prime}$ E), Uitenhage, Eastern Cape Province of South Africa. The Swartkops River and its tributaries, i.e., KwaZunga and Elands rivers, arise in the Groot 
Winterhoek Mountains of the Swartkops catchment and flow into Algoa Bay, and into the Indian Ocean (Figure 1) [47]. The Algoa Bay is an important coastal line in South Africa, known for its marine biodiversity and serving as a habitat and nursery site for various marine animals, including Spheniscus demersus (African penguins), Mirounga leonina (Southern elephant seal), and Sphyrna zygaena (Great white shark) [48].

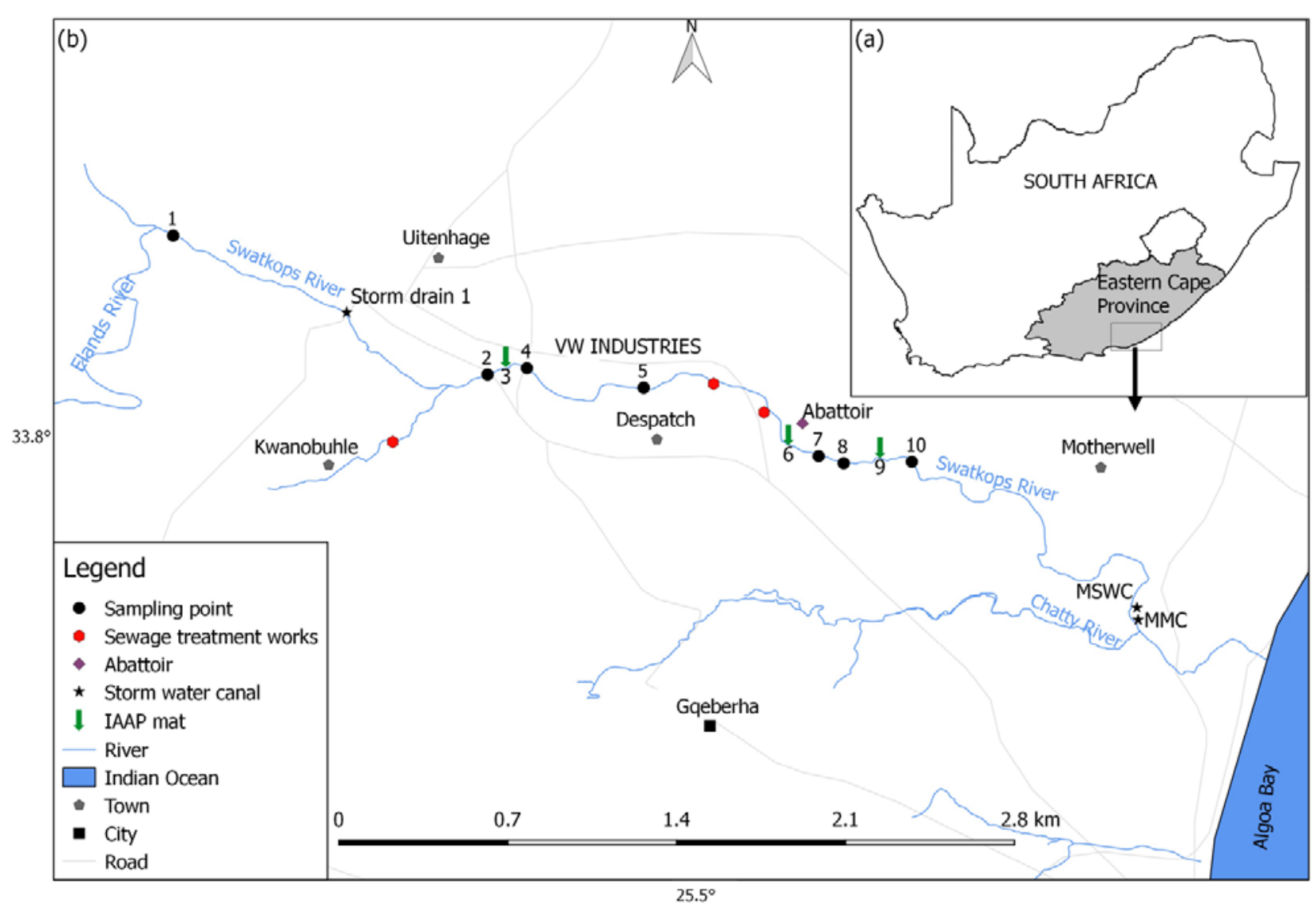

Figure 1. The South African map insert (a) the Swartkops River and tributaries showing 10 sampling locations and land-use activities along the river system (b) Motherwell Storm Canal (MWSC) and Markman Canal (MMC).

The $155 \mathrm{~km}$ long Swartkops River drains the $42 \mathrm{~km}^{2}$ wide catchment area where protected areas dominate the upper reaches of the catchment; the middle reaches is dominated by urban, formal settlements, and agricultural lands; and the lower reaches are surrounded by industries, formal and informal settlements before flowing into the ocean. The landscape activities contribute to the release of domestic effluents, industrial waste, untreated sewage, and other point and non-point source pollutants [49]. The natural vegetation dominating the lower catchment is Bushveld and Succulent thicket, which has been severely altered by the introduction of alien invasive plant species, such as Eucalyptus spp. (Gum trees) and Acacia spp. (Black Wattle and Port Jackson Willow) [49].

Ten study sites were selected along the Swartkops River and sampled for a period of six-months, at monthly intervals, from April 2018 to September 2018. Sample collection took place upstream and downstream of semi and permanent non-native macrophytes mats, P. crassipes and S. molesta (Figure 1). Site 1 was situated among agricultural lands, which was upstream from Uitenhage town but downstream from protected areas. The site experienced minimal urban and industrial effluents except some agricultural inputs (Figure 1). Site 2 was situated downstream from site 1, in the heart of the Uitenhage urban area and after the confluence of Swartkops River and KwaNobuhle tributary. Site 2 was less than $1 \mathrm{~km}$ upstream from P. crassipes mat 1 (hereafter site 3 ), whereas site 4 was located $\sim 0.6 \mathrm{~km}$ downstream from site 3 (Figure 1). Site 5 was $2.4 \mathrm{~km}$ upstream from P. crassipes 
mat 2 (hereafter site 6), and site 7 was about a kilometre downstream from site 6 (Figure 1). Site 8 was located $\sim 1.6 \mathrm{~km}$ upstream from $S$. molesta mat 3 (hereafter site 9), and site 10 was located $0.6 \mathrm{~km}$ downstream from site 9 (Figure 1).

At each site, water and sediment samples together with dominant native (i.e., T. capensis, P. australis, C. sexagularis, and S. pectinatus) and non-native (i.e., P. crassipes and S. molesta) macrophyte species were collected and analysed for heavy metal accumulation analysis (Table S1).

\section{Data Collection}

\subsection{Water Chemistry}

Integrated water sample $(1000 \mathrm{~mL}, n=1)$ was collected $\sim 20 \mathrm{~cm}$ below the water surface at each site using pre-rinsed clear polyethylene sample container for water chemistry analysis. Water samples were then stored on ice until they reached the laboratory, and, within $48 \mathrm{~h}$ after collection, water samples were sent to BEM-Labs, Cape Town, South Africa for water chemistry analysis, including Chemical Oxygen Demand (COD), Zinc $(\mathrm{Zn})$, Iron (Fe), Cadmium (Cd), Arsenic (As), Chromium (Cr), Lead (Pb), Mercury (Hg), and Copper $(\mathrm{Cu})$.

At the laboratory (BEM-Labs), the water samples were acidified to a $\mathrm{pH}$ of \pm 2 and digested to isolate all the metal ions in solution. Once cooled, the samples were filtered through a $0.45 \mu \mathrm{L}$ syringe filter to remove any particulates. The resulting samples were then analysed using an Agilent ICP-OES 720 Axial instrument for total heavy metals. Since these were integrated water samples, it is possible that some properties, such as $\mathrm{pH}$, or organic carbon, varied between the samples and may have influenced the speciation (and bioavailability) of pollutants.

\subsection{Sediment Chemistry}

Using a gardening trowel, integrated soil sediment samples were collected at five areas per site at approximately $10 \mathrm{~cm}$ depth. Sediments samples were collected into plastic zip-lock bags and then stored on ice. Similar to the water chemistry samples, sediment samples were within $48 \mathrm{~h}$ after collection sent to BEM-Labs for sediment chemistry and heavy metal analysis, including $\mathrm{Zn}, \mathrm{Fe}, \mathrm{Cd}, \mathrm{As}, \mathrm{Cr}, \mathrm{Pb}, \mathrm{Hg}$, and $\mathrm{Cu}$.

At BEM-Labs laboratory, a portion of the sediment sample was weighed into an Erlenmeyer flask. We added $20 \mathrm{~mL}$ nitric acid and $10 \mathrm{~mL}$ hydrogen peroxide to the flask, and the flask was then heated to allow the sample to digest. After digestion, the sample was transferred to a $100 \mathrm{~mL}$ volumetric flask, made up to volume, and then filtered. The resulting sample was then analysed on the Agilent ICP-OES 720 Axial instrument for heavy metals.

\subsection{Macrophytes Chemical Analysis}

Native marginal and aquatic vegetation species together with non-native macrophytes were collected at each site for heavy metal analysis. Five stems of emergent plants i.e., T. capensis, C. sexangularis and P. australis; five matured floating plants i.e., P. crassipes and S. molesta, and about $200 \mathrm{~g}$ of submerged plant i.e., S. pectinatus, were collected by hand and rinsed with distilled water to remove any debris and periphyton biofilm.

Plant material were transferred into different zip lock bags (per plant species) and stored on ice until they reached the laboratory. In the laboratory, plant samples were immediately oven-dried at $60{ }^{\circ} \mathrm{C}$ for $72 \mathrm{~h}$. During this procedure, all the cell processes (e.g., respiration) stopped, making sure that samples represents the nutrients composition per gram of leaf without the influence of water. Thereafter, dried leaves were homogenised into coarse material by grinding using a mortar and pestle.

About $6.5 \mathrm{~g}$ of dried plants tissue was weight and packaged into aluminium foil envelopes and also sent to BEM-Labs, for heavy metal analysis, including $\mathrm{Fe}, \mathrm{Hg}, \mathrm{Zn}, \mathrm{Cd}$, $\mathrm{As}, \mathrm{Pb}$, and $\mathrm{Cu}$. For each sample, $20 \mathrm{~mL}$ nitric acid and $5 \mathrm{~mL}$ hydrogen peroxide were added and the flask was heated to allow the sample to digest, until approximately $1 \mathrm{~mL}$ of 
the solution was left. The remaining sample was transferred into a $10 \mathrm{~mL}$ volumetric flask, made up to volume using distilled water and filtered. The filtered sample was analysed on the Agilent ICP-OES 720 Axial instrument for heavy metals.

\section{Data Analysis}

To assess the reduction in water and sediment chemistry between upstream and downstream semi and permanent $P$. crassipes and $S$. molesta mat sites, the percentage reduction in water and sediment heavy metals concentrations were computed. Furthermore, to understand the current environmental condition at Swartkops River and the concentration of heavy metals, sediments and macrophyte indices were used to quantify heavy metal assimilation by both native and non-native macrophytes along the river system.

The geo-accumulation index (Igeo), which measures the degree of heavy metal contamination, was used to estimate heavy metal pollution in the Swartkops River during the study, and this was calculated following the equation defined by Muller [50]:

$$
\text { Igeo }=\log 2\left(\frac{\mathrm{Cn}}{1.5 \mathrm{Bn}}\right)
$$

where $\mathrm{Cn}$ is the measured concentration of metal in sediments, and $\mathrm{Bn}$ is the measured geo-chemical background value of the metal. The 1.5 factor is used to minimize possible variations of the background values, which may be qualified to lithogenic variations [51]. The geo-chemical background values were given according to the world surface rock average as seen in Martin and Meybeck [52].

For further geo-accumulation interpretation, Muller [53] proposed seven classes for the geo-accumulation index, which are used to determine the level of contamination on soil sediments by heavy metals: Class $0=$ Igeo $<0$ (uncontaminated); Class $1=0<$ Igeo $<1$ (uncontaminated to moderately contaminated); Class $2=1<$ Igeo $<2$ (moderately contaminated); Class $3=2<$ Igeo $<3$ (moderately to heavily contaminated); Class $4=3<$ Igeo $<4$ (heavily contaminated); Class $5=4<$ Igeo $<5$ (heavily to extremely contaminated); and Class $6=5<$ Igeo (extremely contaminated).

Secondly, the pollution load index (PLI), which is an important index in evaluating soil sediment quality was used to estimate heavy metal pollution in the sediments. The pollution load index is expressed as the product of the contamination factor $(C F)$ of all measured heavy metals on-site and was calculated following a formula adopted from Islam et al. [54]:

$$
\mathrm{PLI}=\mathrm{CF} 1 \times \mathrm{CF} 2 \times \mathrm{CF} 3 \times \ldots \ldots \mathrm{CFn}) 1 / \mathrm{n}
$$

The Contamination Factor (CF) of each metal was computed separately per site using the metal concentration and the background value of the metal (background value from the average shale value) [55], CF was calculated following Atgin et al. [56].

$$
\mathrm{CF}=\frac{\text { Cm Sample }}{\text { Cm Background }}
$$

where Cm (sample) is the concentration of heavy metal in sediment and Cm (background) is the background value of metals adopted from world surface rock average by Martin and Meybeck [51]. According to Chakravarty and Patgiri [57], the PLI value $<1$, indicates no pollution, whilst PLI value $>1$, indicates pollution (or deterioration of the sediment).

The enrichment factor (EF) is a more comprehensive assessment of heavy metal contamination [58]. The method is based on normalisation of the measured heavy metal concentration with respect to the reference metal, such as Aluminium (Al) or Fe [59]. For the present study, Fe was used as a reference heavy metal for normalization because, according to Nirmala et al. [60], Fe is redox sensitive under oxidation conditions and constitutes significant sinks of heavy metals in aquatic ecosystems.

Background values used for the present study were given according to the world surface rock average by Martin and Meybeck [52]. According to Chen et al. [61], EF < 1, 
indicates no enrichment; $\mathrm{EF}=1-2$, minimal enrichment; $\mathrm{EF}=3-5$, moderate enrichment; $\mathrm{EF}=5-10$, moderately severe enrichment; $\mathrm{EF}=10-25$, severe enrichment; $\mathrm{EF}=25-50$, very severe enrichment; and $E F>50$, extremely severe enrichment. These were calculated following Buat-Menard and Chesselet [62]:

$$
\mathrm{EF}=\frac{\left[\frac{\text { Cmetal }}{\text { Cnormalizer }}\right] \text { Sample }}{\left[\frac{\text { Cmetal }}{\text { Cnormalizer }}\right] \text { Reference metal }(\mathrm{Fe})}
$$

where Cmetal (sample), is the concentration of the examined heavy metal; Cnormalizer (sample), is the concentration of the normalizer/reference heavy metal (Fe); Cmetal (reference metal), is the concentration of the examined heavy metal in its suitable background or baseline reference material, and Cnormalizer (reference metal) is the concentration of the normalizer heavy metal (Fe) in its suitable background.

Then, to assess and estimate the native and non-native macrophyte species accumulation potential for heavy metal concentration in sediments, the bio-concentration factor (BCF) was calculated following Zayed et al. [63]:

$$
\mathrm{BCF}=\frac{[\text { metal plant }]}{[\text { metal sediment }]}
$$

where metal (plant) is the concentration of heavy metals in plants, and metal (sediment) is the concentration of heavy metals in sediments. BCF value $>1$, indicates that the plant species is a better hyper-accumulator of the heavy metal; whereas, $B C F$ value $=1$ indicates that plant species is an accumulator of the heavy metal, and BCF value $<1$ indicates that a plant is a better excluder [64].

To test the significant differences in sediment indices (i.e., Igeo, PLI, and EF) between sites and the macrophyte assimilation factor (BCF) for each plant species, the ShapiroWilk test for normality and Levene test for homogenous variance were employed. The outcome of the tests revealed that none of the variables were normally distributed (ShapiroWilk, $p<0.05$ ) nor were the variances homogenous (Levene test, $p>0.05$ ). Thus, a nonparametric test, in this case, Kruskal-Wallis analysis of variance, with multiple comparison test was employed. All statistical analyses were conducted in R version 3.6.1 [65], except where specified.

\section{Results}

\subsection{Water and Sediment Chemistry}

Heavy metal concentrations were variable along the Swartkops River with no consistent reduction trend downriver (Table S2). The Fe concentration showed significant differences between sites $(H=28.13, p=0.001)$ with site 1 recording high Fe concentration $(1.1 \mathrm{mg} / \mathrm{L})$ and site 10 low concentration $(0.09 \mathrm{mg} / \mathrm{L})$ (Table S2). There was significant difference in $\mathrm{Zn}$ concentration between sites $(H=18.03, p=0.034)$, the highest $\mathrm{Zn}$ concentration $(0.12 \mathrm{mg} / \mathrm{L})$ was recorded at site 10 , and the lowest $\mathrm{Zn}$ concentration $(0.02 \mathrm{mg} / \mathrm{L})$ was recorded for all sites except sites 5 and 7 (Table S2).

The COD concentrations were significantly different between sites $(H=21.89, p=0.001)$. The highest COD concentration was recorded at site $5(57.4 \mathrm{mg} / \mathrm{L})$ and the lowest at site 1 (14.64 mg/L) (Table S2). The As and Cu concentrations were not significantly different, whereas heavy metal, i.e., $\mathrm{Cd}, \mathrm{Cr}, \mathrm{Hg}$, and $\mathrm{Pb}$, concentrations showed constant values of $0.0021,0.026,0.0021$, and $0.006 \mathrm{mg} / \mathrm{L}$, respectively, throughout the sampling period (Table S2).

The sediment chemistry results revealed that the Fe $(H=24.32, p=0.004)$, $\mathrm{Zn}$ $(H=35.75, p<0.001)$, As $(H=17.08, p=0.05), \mathrm{Cr}(H=20.39, p=0.016), \mathrm{Pb}(H=26.19$, $p=0.002)$, and $\mathrm{Cu}(H=26.46, p=0.002)$ concentrations were significantly different between sites (Table S3). Fe (1321.25 mg/kg) and As $(4 \mathrm{mg} / \mathrm{kg})$ were high at site 1 and low at site 5 (Fe: $220.43 \mathrm{mg} / \mathrm{kg}$ ) and site 10 (As: $0.27 \mathrm{mg} / \mathrm{kg}$ ), respectively. 
$\mathrm{Zn}(87.16 \mathrm{mg} / \mathrm{kg}), \mathrm{Cr}(41.12 \mathrm{mg} / \mathrm{kg}), \mathrm{Cu}(5.56 \mathrm{mg} / \mathrm{kg})$, and P (2240.38) were high at site 5 , and low at site 10 (Zn: $7.19 \mathrm{mg} / \mathrm{kg}$ and $\mathrm{Cr}: 8.15 \mathrm{mg} / \mathrm{kg})$ and site $7(\mathrm{Cu}: 0.67 \mathrm{mg} / \mathrm{kg}, \mathrm{P}$ : $281.07 \mathrm{mg} / \mathrm{kg}$ ) (Table S3). The lead concentration was high at site $3(21.10 \mathrm{mg} / \mathrm{kg})$ and the low at site $10(3.67 \mathrm{mg} / \mathrm{kg}$ ) (Table S3). In general, the sediment chemistry results revealed that site 5 had the highest recorded heavy metal concentrations i.e., $\mathrm{Zn}, \mathrm{As}, \mathrm{Cr}, \mathrm{Pb}$, and $\mathrm{Cu}$ (Table S3).

\subsection{Swartkops River Sediment Contamination}

The geo-accumulation index (Igeo) was significantly different for heavy metals i.e., As $(H=17.16, p=0.05), \mathrm{Cr}(H=19.08, p=0.02), \mathrm{Cu}(H=26.47, p<0.001), \mathrm{Fe}(H=24.32$, $p<0.001), \mathrm{Pb}(H=26.19, p<0.001)$, and $\mathrm{Zn}(H=21.40, p=0.01)$ at all sites (Table 1$)$. Cadmium $(H=8.26, p=0.51)$ and $\mathrm{Hg}(H=5.05, p=0.83)$ were not significantly different at all sites, and showed negative $(-)$ Igeo values, which are indicative of uncontaminated sediments (Table 1).

Geo-accumulation index values revealed that sites were extremely contaminated by $\mathrm{Cr}, \mathrm{Fe}$ and $\mathrm{Zn}$, recording Igeo values of more than 5 . Site 5 recorded the highest Igeo value for $\mathrm{Zn}$ (12.16) and $\mathrm{Cr}$ (11.06) whereas, site 1 recorded the highest Igeo value for Fe (15.11) (Table 1). All sites were extremely contaminated (Igeo $>5$ ) with $\mathrm{Pb}$ and $\mathrm{Cr}$, except site $9(\mathrm{~Pb})$ and site $10(\mathrm{~Pb}$ and $\mathrm{Cr})$. Arsenic recorded the lowest Igeo values ranging from -0.64 , uncontaminated sediments (site 3), to 2.94, moderately contaminated (site 1) (Table 1).

The enrichment factor $(\mathrm{EF})$ revealed that five heavy metals, including As $(H=17.08$, $p=0.05), \mathrm{Cr}(H=20.39, p=0.02), \mathrm{Cu}(H=26.47, p<0.001), \mathrm{Zn}(H=35.80, p<0.001)$, and $\mathrm{Pb}$ $(H=26.19, p<0.001)$, showed significant differences between sites (Table 1$)$. Site 1 recorded high $\mathrm{EF}$ values for majority of heavy metals, i.e., As, $\mathrm{Cr}, \mathrm{Cu}$, and $\mathrm{Hg}$, whilst site 5 revealed high EF for heavy metals, i.e., $\mathrm{Zn}$, and $\mathrm{Pb}$ (Table 1).

Based on the EF values obtained, all sites experienced no enrichment except for site 1, which showed minimal Hg enrichment (Table 1). The PLI values were not significantly different between sampling periods (Kruskal-Wallis ANOVA, $p>0.05$ ) (Table 1). All recorded PLI values were below 1, except site 5, which recorded PLI value of 1.10 for the month of April. In general, the month of June recorded PLI > 1 for majority of sites; however, they were all not significantly different. 


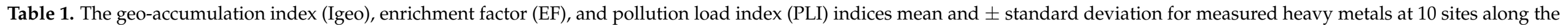
Swartkops River system over a period of six months (April 2018-September 2018). Bolded H-values indicate significant differences (Kruskal-Wallis ANOVA, $p<0.05$ ).

\begin{tabular}{|c|c|c|c|c|c|c|c|c|c|c|c|c|}
\hline $\begin{array}{l}\text { Sediment } \\
\text { Indices }\end{array}$ & $\begin{array}{l}\text { Heavy } \\
\text { Metals }\end{array}$ & 1 & 2 & 3 & 4 & 5 & 6 & 7 & 8 & 9 & 10 & $\begin{array}{c}H- \\
\text { Value }\end{array}$ \\
\hline \multirow[t]{8}{*}{ IGEO } & As & $2.94 \pm 1.70$ & $0.79 \pm 0.89$ & $-0.64 \pm 1.71$ & $1.15 \pm 1.45$ & $1.81 \pm 0.81$ & $1.53 \pm 1.45$ & $0.34 \pm 0.57$ & $0.81 \pm 2.58$ & $0.03 \pm 1.22$ & $0.26 \pm 0.63$ & 17.16 \\
\hline & $\mathrm{Cd}$ & $-2.32 \pm 2.15$ & $-3.07 \pm 3.03$ & $-4.44 \pm 2.87$ & $-5.00 \pm 3.62$ & $-3.09 \pm 2.88$ & $-1.10 \pm 2.46$ & $-2.56 \pm 3.15$ & $-1.19 \pm 2.67$ & $-2.06 \pm 2.86$ & $-2.12 \pm 2.94$ & 8.26 \\
\hline & $\mathrm{Cr}$ & $9.38 \pm 0.44$ & $9.76 \pm 0.85$ & $9.91 \pm 0.85$ & $9.69 \pm 0.89$ & $11.06 \pm 0.86$ & $9.77 \pm 0.79$ & $9.07 \pm 0.55$ & $9.29 \pm 0.85$ & $8.90 \pm 0.91$ & $8.85 \pm 0.57$ & 19.08 \\
\hline & $\mathrm{Cu}$ & $5.60 \pm 0.65$ & $7.14 \pm 0.23$ & $6.41 \pm 0.58$ & $5.48 \pm 1.37$ & $7.02 \pm 1.66$ & $6.45 \pm 1.26$ & $4.41 \pm 0.50$ & $6.20 \pm 0.57$ & $5.38 \pm 0.58$ & $4.92 \pm 0.21$ & 26.47 \\
\hline & $\mathrm{Fe}$ & $15.11 \pm 0.86$ & $14.67 \pm 0.81$ & $14.79 \pm 0.45$ & $13.80 \pm 0.84$ & $12.50 \pm 0.96$ & $13.97 \pm 0.64$ & $12.70 \pm 1.11$ & $14.33 \pm 0.96$ & $13.86 \pm 0.61$ & $13.91 \pm 1.10$ & 24.32 \\
\hline & $\mathrm{Hg}$ & $-6.64 \pm 3.63$ & $-6.20 \pm 2.52$ & $-6.29 \pm 2.03$ & $-7.02 \pm 2.09$ & $-6.07 \pm 2.09$ & $-7.62 \pm 3.05$ & $-6.97 \pm 1.65$ & $-6.36 \pm 1.71$ & $-7.09 \pm 2.52$ & $-6.67 \pm 1.78$ & 5.05 \\
\hline & $\mathrm{Pb}$ & $7.44 \pm 0.62$ & $7.61 \pm 0.81$ & $8.04 \pm 0.60$ & $6.75 \pm 1.19$ & $7.95 \pm 0.58$ & $5.33 \pm 3.02$ & $5.04 \pm 3.15$ & $6.29 \pm 1.48$ & $3.81 \pm 3.56$ & $3.66 \pm 3.43$ & 26.19 \\
\hline & $\mathrm{Zn}$ & $8.77 \pm 0.66$ & $11.83 \pm 0.64$ & $11.37 \pm 0.16$ & $10.46 \pm 1.12$ & $12.16 \pm 1.17$ & $10.06 \pm 0.93$ & $9.06 \pm 0.84$ & $10.22 \pm 0.93$ & $9.44 \pm 0.29$ & $8.79 \pm 0.36$ & 21.40 \\
\hline \multirow[t]{7}{*}{$\mathrm{EF}$} & As & $0.02 \pm 0.01$ & 0 & 0 & 0 & 0 & 0 & 0 & 0 & 0 & 0 & 17.08 \\
\hline & $\mathrm{Cd}$ & $0.01 \pm 0.01$ & 0 & 0 & $0.01 \pm 0.02$ & 0 & 0 & 0 & 0 & 0 & 0 & 8.26 \\
\hline & $\mathrm{Cr}$ & $0.01 \pm 0.01$ & 0 & 0 & 0 & 0 & 0 & 0 & 0 & 0 & 0 & 20.39 \\
\hline & $\mathrm{Cu}$ & $0.01 \pm 0.01$ & 0 & 0 & 0 & 0 & 0 & 0 & 0 & 0 & 0 & 26.47 \\
\hline & $\mathrm{Hg}$ & $1.09 \pm 1.70$ & $0.93 \pm 1.31$ & $0.66 \pm 0.87$ & $0.38 \pm 0.46$ & $0.71 \pm 0.80$ & $0.46 \pm 0.76$ & $0.33 \pm 0.42$ & $0.51 \pm 0.62$ & $0.52 \pm 0.74$ & $0.44 \pm 0.58$ & 1.76 \\
\hline & $\mathrm{Pb}$ & $0.01 \pm 0$ & $0.01 \pm 0$ & $0.02 \pm 0$ & 0 & $0.02 \pm 0$ & $0.01 \pm 0$ & 0 & 0 & 0 & 0 & 26.19 \\
\hline & $\mathrm{Zn}$ & 0 & $0.01 \pm 0$ & $0 \pm 0$ & 0 & $0.02 \pm 0$ & 0 & 0 & 0 & 0 & 0 & 35.80 \\
\hline \multirow[t]{3}{*}{ PLI } & April & 0.86 & 0.63 & 0.43 & 0.25 & 1.10 & 0.00 & 0.00 & 0.00 & 0.00 & 0.00 & 9 \\
\hline & May & 0.00 & 0.00 & 0.63 & 0.43 & 0.00 & 0.00 & 0.00 & 0.00 & 0.00 & 0.00 & 9 \\
\hline & Aug & 0.52 & 0.00 & 0.90 & 0.98 & 0.85 & 0.00 & 0.00 & 0.00 & 0.00 & 0.00 & 9 \\
\hline
\end{tabular}




\subsection{Heavy Metal Assimilation along the Swartkops River}

Pontederia crassipes and Salvinia molesta semi and permanent mats showed promising heavy metal assimilation, but this varied between sites. However, in some cases, the trend was clear showing heavy metal reduction between upstream and downstream $P$. crassipes and S. molesta mats, thus, indicating possible macrophyte assimilation potential (Table S4).

The Fe concentration in the sediments showed a $46 \%$ reduction between the upstream site $2(967.37 \mathrm{mg} / \mathrm{kg})$ and downstream site $4(520.02 \mathrm{mg} / \mathrm{kg})$ of $P$. crassipes mat (site 3), whereas $\mathrm{Zn}$ concentration showed a total reduction of $57 \%, 89 \%$, and $65 \%$ between site 2 $(62.55 \mathrm{mg} / \mathrm{kg})$ and site $4(26.92 \mathrm{mg} / \mathrm{kg})$, site $5(87.16 \mathrm{mg} / \mathrm{kg})$ and site $7(9.65 \mathrm{mg} / \mathrm{kg})$, site $8(22.4 \mathrm{mg} / \mathrm{kg}$ ) and site $10(7.19 \mathrm{mg} / \mathrm{kg})$, respectively (Table S4). Arsenic showed a total reduction of $81 \%$ and $83 \%$ between site $5(1.49 \mathrm{mg} / \mathrm{kg})$ and site $7(0.28 \mathrm{mg} / \mathrm{kg})$ as well as site $8(1.55 \mathrm{mg} / \mathrm{kg})$ and $10(0.27 \mathrm{mg} / \mathrm{kg})$, respectively (Table S4).

Chromium showed a $77 \%$ reduction between site $5(41.12 \mathrm{mg} / \mathrm{kg})$ and site $7(9.50 \mathrm{mg} / \mathrm{kg})$, and $\mathrm{Pb}$ showed a $68 \%$ reduction between site $5(19.90 \mathrm{mg} / \mathrm{kg})$ and site $7(6.45 \mathrm{mg} / \mathrm{kg})$, and $56 \%$ reduction between site $8(8.42 \mathrm{mg} / \mathrm{kg})$ and site $10(3.67 \mathrm{mg} / \mathrm{kg})$ (Table S4). Mercury was reduced by $59 \%$ between site $2(1.77 \mathrm{mg} / \mathrm{kg})$ and site $4(0.72 \mathrm{mg} / \mathrm{kg})$ and by $53 \%$ between site $5(1.36 \mathrm{mg} / \mathrm{kg})$ and site $7(0.64 \mathrm{mg} / \mathrm{kg})$ (Table S4).

Emergent native macrophytes species recorded the lowest bio-concentration factor (BCF) values when compared to both floating and submerged native macrophyte species (Table 2). Typha capensis and Cyperus sexangularis BCF results were significant between sites for $\mathrm{Cu}(H=21.11, p=0.01 ; H=25.39, p=0.002)$ and $\mathrm{Zn}(H=37.34, p<0.001 ; H=38.45$, $p<0.001$ ) (Table 2). Typha capensis and C. sexangularis showed a BCF value of less than 1 for $\mathrm{Cu}$ at all sites; however, for $\mathrm{Zn}$, T. capensis recorded a BCF of less than 1 at sites 1, 6, 7, 8, 9, and 10, whereas C. sexangularis recorded BCF of less than 1 at sites $1,7,8,9$, and 10 (Table 2). Phrgamites australis showed significantly different BCF values for $\mathrm{Zn}(H=16.43, p=0.05)$, at all sites, except for site 5 , which showed BCF values of less than 1 (Table 2).

The floating non-native $P$. crassipes $\mathrm{BCF}$ results were significantly different between sites for As $(H=23.15, p<0.01), \mathrm{Cr}(H=23.32, p<0.001), \mathrm{Cu}(H=24.4, p<0.001), \mathrm{Fe}$ $(H=26.94, p<0.001), \mathrm{Hg}(H=20.76, p<0.01)$, and $\mathrm{Zn}(H=27.7, p<0.001)$ (Table 2). Pontederia crassipes recorded $\mathrm{BCF}$ values of less than $1 \mathrm{for} \mathrm{Cu}$ and $\mathrm{Zn}$ at all sites; whilst As recorded $\mathrm{BCF}>1$ for site 1 and site 9, and $\mathrm{Hg} \mathrm{BCF}>1$ at sites $6,7,9$, and 10 (Table 2).

The submerged macrophyte $S$. pectinata $\mathrm{BCF}$ results were significantly different for four heavy metals, i.e., $\mathrm{Cr}(H=27.33, p<0.001)$, $\mathrm{Fe}(H=23.64, p=0.05), \mathrm{Hg}(H=16.77$, $p=0.05)$, and $\mathrm{Zn}(H=22.08, p<0.01)$ (Table 2). The heavy metals Fe, $\mathrm{Hg}$, and $\mathrm{Zn}$ recorded $\mathrm{BCF}$ of less than 1 for all sites, whilst $\mathrm{Cr}$ recorded BCF $>1$ at sites 6, 7, and 9 (Table 2). The significant $\mathrm{BCF}$ values for S. pectinata species were in decreasing order of $\mathrm{Hg}>\mathrm{Zn}>\mathrm{Fe}>\mathrm{Cr}$, indicating that $\mathrm{S}$. pectinata assimilated $\mathrm{Hg}$ more effectively compared to $\mathrm{Cr}$ (Table 2). 


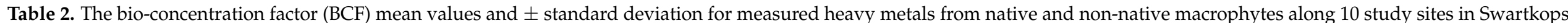

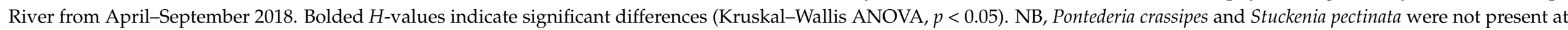
site 1 throughout the study, hence, BCF values $=0$ for all heavy metals.

\begin{tabular}{|c|c|c|c|c|c|c|c|c|c|c|c|c|}
\hline \multirow{2}{*}{ Plant Species } & \multirow{2}{*}{$\begin{array}{l}\text { Heavy } \\
\text { Metals }\end{array}$} & \multicolumn{10}{|c|}{ Sites } & \multirow{2}{*}{$H$-Value } \\
\hline & & 1 & 2 & 3 & 4 & 5 & 6 & 7 & 8 & 9 & 10 & \\
\hline \multirow[t]{6}{*}{ T. capensis } & As & $0.05 \pm 0.07$ & $0.25 \pm 0.24$ & $2.18 \pm 2.89$ & $0.39 \pm 0.48$ & $0.21 \pm 0.12$ & $0.37 \pm 0.43$ & $0.11 \pm 0.24$ & $1.55 \pm 2.83$ & $0.66 \pm 1.25$ & $0.08 \pm 0.17$ & 13.05 \\
\hline & $\mathrm{Cd}$ & 0 & $0.07 \pm 0.11$ & $0.57 \pm 0.611$ & $1.10 \pm 1.17$ & $0.08 \pm 0.09$ & $1.75 \pm 3.90$ & $0.06 \pm 0.13$ & $0.03 \pm 0.06$ & $0.04 \pm 0.09$ & $0.05 \pm 0.10$ & 13.22 \\
\hline & $\mathrm{Cu}$ & $3.33 \pm 1.77$ & $1.32 \pm 0.30$ & $1.91 \pm 0.70$ & $3.86 \pm 2.91$ & $1.97 \pm 2.97$ & $1.93 \pm 1.04$ & $4.35 \pm 1.74$ & $1.99 \pm 1.16$ & $2.86 \pm 0.90$ & $3.87 \pm 1.06$ & 21.11 \\
\hline & $\mathrm{Fe}$ & $0.34 \pm 0.22$ & $0.46 \pm 0.28$ & $0.39 \pm 0.24$ & $0.77 \pm 0.65$ & $2.10 \pm 1.68$ & $0.25 \pm 0.08$ & $0.76 \pm 0.43$ & $0.23 \pm 0.16$ & $0.41 \pm 0.23$ & $0.51 \pm 0.38$ & 16.06 \\
\hline & $\mathrm{Hg}$ & $4.19 \pm 6.65$ & $0.76 \pm 0.60$ & $0.93 \pm 0.98$ & $1.16 \pm 1.15$ & $0.57 \pm 0.31$ & $3.82 \pm 4.57$ & $0.83 \pm 0.78$ & $1.12 \pm 1.45$ & $1.42 \pm 2.23$ & $0.72 \pm 0.54$ & 1.83 \\
\hline & $\mathrm{Pb}$ & $0.08 \pm 0.10$ & $0.05 \pm 0.05$ & $0.04 \pm 0.05$ & $0.13 \pm 0.12$ & $0 \pm 0.01$ & $0.12 \pm 0.17$ & $0.19 \pm 0.23$ & $0.22 \pm 0.30$ & $0.07 \pm 0.10$ & $0.09 \pm 0.13$ & 2.76 \\
\hline \multirow[t]{8}{*}{ C. sexangularis } & As & $0.05 \pm 0.06$ & $0.25 \pm 0.24$ & $2.35 \pm 2.95$ & $0.39 \pm 0.48$ & $0.23 \pm 0.19$ & $0.48 \pm 0.63$ & $0.11 \pm 0.24$ & $1 \pm 1.75$ & $0.48 \pm 0.52$ & $0.08 \pm 0.18$ & 11.20 \\
\hline & $\mathrm{Cd}$ & $0.21 \pm 0.35$ & $0.12 \pm 0.22$ & $0.37 \pm 0.60$ & $1.10 \pm 1.17$ & $0.22 \pm 0.34$ & $0.14 \pm 0.32$ & $0.06 \pm 0.13$ & $0.04 \pm 0.08$ & $0.03 \pm 0.07$ & $0.05 \pm 0.10$ & 11.02 \\
\hline & $\mathrm{Cr}$ & $0.57 \pm 0.16$ & $0.55 \pm 0.38$ & $0.58 \pm 0.50$ & $0.64 \pm 0.35$ & $0.21 \pm 0.12$ & $0.52 \pm 0.32$ & $0.68 \pm 0.52$ & $0.60 \pm 0.55$ & $0.65 \pm 0.47$ & $0.98 \pm 0.47$ & 11.49 \\
\hline & $\mathrm{Cu}$ & $2.34 \pm 1.50$ & $1.73 \pm 0.21$ & $2.21 \pm 0.59$ & $3.86 \pm 2.91$ & $2.13 \pm 2.90$ & $2.30 \pm 2.11$ & $4.35 \pm 1.74$ & $1.24 \pm 0.41$ & $2.59 \pm 2.29$ & $3.87 \pm 1.06$ & 25.39 \\
\hline & $\mathrm{Fe}$ & $0.38 \pm 0.20$ & $0.28 \pm 0.14$ & $0.39 \pm 0.23$ & $0.77 \pm 0.65$ & $2.37 \pm 2.17$ & $0.67 \pm 0.44$ & $0.76 \pm 0.43$ & $0.24 \pm 0.13$ & $0.31 \pm 0.09$ & $0.51 \pm 0.38$ & 15.87 \\
\hline & $\mathrm{Hg}$ & $0.30 \pm 0.13$ & $0.471 \pm 0.55$ & $0.88 \pm 0.85$ & $1.16 \pm 1.15$ & $0.66 \pm 0.41$ & $2.64 \pm 2.68$ & $0.83 \pm 0.78$ & $0.48 \pm 0.39$ & $1.04 \pm 1.57$ & $0.72 \pm 0.54$ & 10.10 \\
\hline & $\mathrm{Pb}$ & $0.09 \pm 0.09$ & $0.05 \pm 0.05$ & $0.05 \pm 0.05$ & $0.13 \pm 0.12$ & $0.06 \pm 0.08$ & $0.08 \pm 0.10$ & $0.19 \pm 0.23$ & $0.16 \pm 0.14$ & $0.09 \pm 0.10$ & $0.09 \pm 0.13$ & 3.77 \\
\hline & $\mathrm{Zn}$ & $4.74 \pm 2.59$ & $0.97 \pm 0.56$ & $0.29 \pm 0.06$ & $0.76 \pm 0.84$ & $0.28 \pm 0.32$ & $0.86 \pm 0.40$ & $5.47 \pm 2.79$ & $2.45 \pm 1.28$ & $3.75 \pm 0.91$ & $4.18 \pm 1.86$ & 38.49 \\
\hline \multirow[t]{7}{*}{ P. australis } & As & $0.10 \pm 0.08$ & $0.11 \pm 0.16$ & $1.75 \pm 2.44$ & $0.14 \pm 0.31$ & $0.09 \pm 0.20$ & $0.18 \pm 0.30$ & $0.01 \pm 0.03$ & $0.08 \pm 0.11$ & $0.15 \pm 0.20$ & $0.09 \pm 0.20$ & 4.25 \\
\hline & $\mathrm{Cr}$ & $0.59 \pm 0.41$ & $0.29 \pm 0.24$ & $0.25 \pm 0.17$ & $0.25 \pm 0.19$ & $0.10 \pm 0.18$ & $0.53 \pm 0.40$ & $0.63 \pm 0.53$ & $0.64 \pm 0.52$ & $0.86 \pm 0.63$ & $0.70 \pm 0.79$ & 12.02 \\
\hline & $\mathrm{Cu}$ & $1.38 \pm 0.73$ & $0.58 \pm 0.34$ & $0.89 \pm 0.20$ & $1.41 \pm 0.97$ & $0.47 \pm 0.42$ & $1.85 \pm 1.94$ & $2.06 \pm 1.65$ & $0.86 \pm 0.64$ & $1.82 \pm 1.52$ & $1.97 \pm 1.34$ & 11.73 \\
\hline & $\mathrm{Fe}$ & $0.38 \pm 0.28$ & $0.36 \pm 0.34$ & $0.46 \pm 0.36$ & $1.30 \pm 1.74$ & $0.88 \pm 1.17$ & $0.33 \pm 0.31$ & $0.54 \pm 0.48$ & $0.14 \pm 0.13$ & $0.47 \pm 0.66$ & $0.38 \pm 0.16$ & 9.58 \\
\hline & $\mathrm{Hg}$ & $0.31 \pm 0.18$ & $0.53 \pm 0.58$ & $0.64 \pm 0.81$ & $0.60 \pm 0.54$ & $0.28 \pm 0.47$ & $1.46 \pm 1.37$ & $0.91 \pm 1.28$ & $0.51 \pm 0.61$ & $1.47 \pm 2.49$ & $0.78 \pm 0.67$ & 4.12 \\
\hline & $\mathrm{Pb}$ & $0.07 \pm 0.07$ & $0.04 \pm 0.05$ & $0.04 \pm 0.06$ & $0.07 \pm 0.10$ & 0 & $0.04 \pm 0.09$ & $0.09 \pm 0.13$ & $0.07 \pm 0.10$ & $0.03 \pm 0.08$ & $0.09 \pm 0.13$ & 2.30 \\
\hline & $\mathrm{Zn}$ & $3.70 \pm 1.72$ & $1.40 \pm 1.00$ & $1.67 \pm 1.13$ & $2.36 \pm 2.72$ & $0.63 \pm 0.57$ & $3.27 \pm 2.55$ & $2.56 \pm 1.84$ & $1.56 \pm 1.13$ & $6.53 \pm 9.05$ & $6.18 \pm 4.23$ & 16.43 \\
\hline \multirow[t]{8}{*}{ P. crassipes } & As & 0 & $0.15 \pm 0.16$ & 0 & 0 & $0.13 \pm 0.12$ & $0.23 \pm 0.51$ & 0 & $1.54 \pm 2.64$ & $1.08 \pm 1.34$ & $0.10 \pm 0.17$ & 23.15 \\
\hline & $\mathrm{Cd}$ & 0 & $1.18 \pm 2.61$ & $0.09 \pm 0.15$ & $0.25 \pm 0.43$ & $0.41 \pm 0.86$ & $0.03 \pm 0.07$ & $0.07 \pm 0.15$ & $0.04 \pm 0.08$ & $0.03 \pm 0.07$ & $0.06 \pm 0.13$ & 4.28 \\
\hline & $\mathrm{Cr}$ & 0 & $0.45 \pm 0.21$ & $0.35 \pm 0.22$ & $0.40 \pm 0.20$ & $0.13 \pm 0.07$ & $0.29 \pm 0.14$ & $0.37 \pm 0.28$ & $0.51 \pm 0.28$ & $0.82 \pm 0.42$ & $0.80 \pm 0.62$ & 28.32 \\
\hline & $\mathrm{Cu}$ & 0 & $1.70 \pm 0.66$ & $2.79 \pm 0.99$ & $7.10 \pm 7.08$ & $3.43 \pm 4.21$ & $1.99 \pm 1.38$ & $8.01 \pm 4.07$ & $2.23 \pm 0.68$ & $3.93 \pm 2.60$ & $4.86 \pm 3.09$ & 24.40 \\
\hline & $\mathrm{Fe}$ & 0 & $0.52 \pm 0.29$ & $0.41 \pm 0.24$ & $0.86 \pm 0.63$ & $1.88 \pm 0.99$ & $0.27 \pm 0.15$ & $0.77 \pm 0.54$ & $0.81 \pm 0.73$ & $0.98 \pm 0.64$ & $1.15 \pm 0.95$ & 29.94 \\
\hline & $\mathrm{Hg}$ & 0 & $0.41 \pm 0.36$ & $0.44 \pm 0.85$ & $0.55 \pm 1.08$ & $0.33 \pm 0.24$ & $1.25 \pm 1.21$ & $1.29 \pm 1.48$ & $0.59 \pm 0.52$ & $1.35 \pm 2.19$ & $1.10 \pm 0.78$ & 20.76 \\
\hline & $\mathrm{Pb}$ & 0 & $0.11 \pm 0.12$ & $0.01 \pm 0.01$ & $0.04 \pm 0.07$ & $0.08 \pm 0.08$ & $0.09 \pm 0.12$ & $0.21 \pm 0.25$ & $0.24 \pm 0.33$ & $0.09 \pm 0.11$ & $0.21 \pm 0.24$ & 12.82 \\
\hline & $\mathrm{Zn}$ & 0 & $2.46 \pm 2.08$ & $1.35 \pm 0.51$ & $2.95 \pm 2.44$ & $1.65 \pm 1.68$ & $3.36 \pm 1.25$ & $8.34 \pm 5.74$ & $2.32 \pm 1.18$ & $4.47 \pm 1.93$ & $5.94 \pm 3.38$ & 27.70 \\
\hline
\end{tabular}


Table 2. Cont.

\begin{tabular}{|c|c|c|c|c|c|c|c|c|c|c|c|c|}
\hline $\begin{array}{c}\text { Plant } \\
\text { Species }\end{array}$ & $\begin{array}{l}\text { Heavy } \\
\text { Metals }\end{array}$ & 1 & 2 & 3 & 4 & 5 & $\begin{array}{l}\text { Sites } \\
\\
\end{array}$ & 7 & 8 & 9 & 10 & $\begin{array}{c}H- \\
\text { Value }\end{array}$ \\
\hline \multirow{6}{*}{$\begin{array}{c}S . \\
\text { pectinata }\end{array}$} & As & 0 & $0.23 \pm 0.28$ & $2.69 \pm 4.51$ & $0.29 \pm 0.29$ & $0.18 \pm 0.18$ & $0.38 \pm 0.57$ & $0.22 \pm 0.34$ & $2.88 \pm 6.40$ & $0.44 \pm 0.70$ & $0.20 \pm 0.33$ & 11.42 \\
\hline & $\mathrm{Cr}$ & 0 & $0.71 \pm 0.54$ & $0.64 \pm 0.47$ & $0.74 \pm 0.44$ & $0.65 \pm 0.33$ & $1.58 \pm 0.88$ & $1.60 \pm 0.64$ & $0.99 \pm 0.77$ & $1.60 \pm 1.44$ & $0.97 \pm 0.37$ & 27.33 \\
\hline & $\mathrm{Cu}$ & 0 & $112.32 \pm 141.42$ & $83.46 \pm 76.84$ & $178.19 \pm 262.57$ & $112.59 \pm 117.41$ & $809.31 \pm 1561.55$ & $52.59 \pm 45.09$ & $33.02 \pm 27.44$ & $54.84 \pm 65.20$ & $19.88 \pm 22.27$ & 15.11 \\
\hline & $\mathrm{Fe}$ & 0 & $2.01 \pm 2.34$ & $1.54 \pm 1.68$ & $3.79 \pm 5.46$ & $11.76 \pm 8.44$ & $3.26 \pm 1.87$ & $18.77 \pm 17.96$ & $2.70 \pm 1.81$ & $3.47 \pm 2.15$ & $3.96 \pm 4.83$ & 23.64 \\
\hline & $\mathrm{Hg}$ & 0 & $13.17 \pm 17.67$ & $9.38 \pm 10.54$ & $19.85 \pm 30.46$ & $9.40 \pm 10.92$ & $71.04 \pm 128.50$ & $6.87 \pm 9.13$ & $1.13 \pm 1.18$ & $7.19 \pm 8.81$ & $2.09 \pm 2.51$ & 16.77 \\
\hline & $\mathrm{Zn}$ & 0 & $5.79 \pm 2.63$ & $5.60 \pm 1.80$ & $10.99 \pm 5.59$ & $5.41 \pm 6.69$ & $18.95 \pm 13.17$ & $15.86 \pm 16.06$ & $4.42 \pm 3.00$ & $8.73 \pm 1.35$ & $11.22 \pm 4.40$ & 22.08 \\
\hline
\end{tabular}




\section{Discussion}

The present study reports that the Swartkops River system is heavily polluted by various heavy metals. Although our results show some degree of assimilation by native and non-native macrophyte stands, the continuous inputs, i.e., non-point sources, at different entry points along the river system surpass this potential. Research on macrophyte assimilation (or phytoremediation) has mainly been conducted in mesocosm settings, with limited in situ case studies or case studies in the natural environment [23,66-68].

The effectiveness of phytoremediation in the reduction of heavy metal concentrations in water and sediment by non-native P. crassipes and S. molesta was tested in the present study and others (e.g., $[19,29,69,70])$. Although the results did not show a consistent decreasing trend due to high variation between sites, the present study's findings still showed promising macrophyte assimilation potential as most sites showed reduced concentrations of heavy metals as hypothesized. The Swartkops River is in a deteriorating state, and these findings have been corroborated by a number of studies before (see [49,71-73]), which revealed that intense land-use developments along the Swartkops River catchment and riparian areas have a huge effect on the system's physical, chemical, and biological well-being.

Findings from the present study revealed that there were few significant reductions in heavy metal concentrations between the immediate upstream and downstream sites within individual non-native macrophyte patch. For example, between site 2 and site 4 upstream and downstream of P. crassipes mat (site 3), as well as site 8 and site 10 of S. molesta mat (site 9), we reported more than $45 \%$ reduction in heavy metal concentration (i.e., $\mathrm{Zn}, \mathrm{Cr}, \mathrm{As}$, $\mathrm{Pb}$, and $\mathrm{Hg}$ ) (Table S4).

Reductions were attributed to the presence of $P$. crassipes and S. molesta mats acting as accumulators for heavy metals from upstream. The above findings corroborated with Mishra and Tripathi [19], whose study reported on the effectiveness of $P$. crassipes in accumulation of $\mathrm{Cr}$ and $\mathrm{Zn}$ effluents, were $P$. crassipes efficiently assimilated more than $50 \%$ of the heavy metal concentration in only 11 days of exposure, further emphasizing the phytoremediation potential of these macrophytes.

It is possible that some of the pollutants were accumulated by sediments. This is because, as contaminants constantly wash off downriver, some slowly settles and gets assimilated in the sediments. Jernström et al. [74] indicated that the nature of sediments in water bodies reflects, to a great extent, the condition of the system as a result of various pollutants in the water; in addition, these sediments may also serve as indicators by revealing the concentration of the pollutants settling in them.

These results were supported by Hadad et al. [75] and Schaller et al. [76], who reported that the top sediment layer, integrated with a low diffusion rate of elements can play a significant role in adsorption and accumulation of heavy metals. Various indices from the present study, including EF, PLI, and Igeo, showed that sediments along the Swartkops River system were moderately to extremely contaminated as a result of pollutants along the river catchment (Table 1).

These findings were more evident at site 5, which recorded the highest heavy metal concentrations (i.e., $\mathrm{Zn}, \mathrm{As}, \mathrm{Cr}, \mathrm{Cu}$, and $\mathrm{Pb}$ ) in sediments, in addition, the $\mathrm{EF}$ and Igeo values were highest for $\mathrm{Zn}$ and $\mathrm{Pb}$, revealing extreme sediment contamination by these heavy metals at site 5 (Table 1). This emphasize that the Swartkops River is facing probable environmental pollution especially with heavy metals, i.e., $\mathrm{Fe}, \mathrm{Cu}, \mathrm{Cr}, \mathrm{Zn}$, and $\mathrm{Pb}$.

The bio-concentration factor (BCF) index also showed that T. capensis, C. sexangularis, P. australis (native emergent macrophytes), S. pectinatus (native submerged macrophyte), and $P$. crassipes (invasive floating macrophyte) have promising assimilation potential. Various studies (i.e., $[15,77-79]$ ) have shown that $T$. capensis, $C$. sexangularis, and P. australis are good heavy metal accumulators. The present study, although variable, were consistent with the above mentioned studies revealing that these macrophyte species are great accumulators of various heavy metals.

This was because both studies showed reductions in heavy metal concentrations indicating phytoremediation potential by native and non-native macrophytes. Despite the macro- 
phyte assimilation potential, few hyper-accumulated heavy metals were recorded when compared to what other studies had achieved when using the same macrophytes species $[15,78,79]$ This could be attributed to fact that the present study only used C. sexangularis, P. autralis, and $T$. capensis species leaves for heavy metal analysis. Macrophytes assimilate heavy metals; however, their concentrations differ with plant parts or segments. For example, Vymazal and Březinová [80] reported that the assimilation and distribution of heavy metals in above-ground parts differs from below-ground plant parts, and this is because of different physiological absorption mechanisms in plants. Other studies, including Chandra and Yadav [77], Eid et al. [70], Bonanno [81], and Vymazal and Březinová [80], supported these findings by revealing that emergent macrophytes species, including Phragmites spp., Cyperus spp., and Typha spp., usually have similar accumulation trends.

These macrophytes species accumulate larger quantities of certain heavy metals, including $\mathrm{Cr}, \mathrm{Mn}, \mathrm{Cu}, \mathrm{Ni}, \mathrm{Hg}, \mathrm{Pb}$, and $\mathrm{Zn}$, better in underground plant parts as compared to above-ground plant parts, and this is usually in the order of roots $>$ rhizomes $>$ leaves $>$ stems. Although the present study did not evaluate heavy metal concentrations for below ground plant parts for P. australis, C. sexangularis, and T. capensis, the accumulated heavy metal concentrations and low BCF values recorded in emergent macrophytes could have been influenced by the same trend, which is variation in the distribution within the plant parts, which may also differ with plant size.

In contrast, floating (non-native) and submerged (native) species revealed a greater uptake of heavy metals (i.e., $\mathrm{Cr}, \mathrm{Fe}, \mathrm{Hg}$, and $\mathrm{Zn}$ ) with high $\mathrm{BCF}$ values compared to emergent macrophytes (Table 2). This was expected for P. crassipes, as it is known for a high accumulation ability and tolerance to disturbances. The high uptake of heavy metals by S. pectinatus could have been solely influenced by using the whole plant (roots, stem, and leaves), which were fully exposed to heavily polluted systems.

The present study further revealed that $P$. crassipes was the most effective accumulator of heavy metals, followed S. pectinatus, P. australis, C. sexangularis, and T. capensis. The order of accumulation in heavy metals by macrophyte species (floating, emerged, and submerged) was similar to a study by Goulet et al. [82] who tested floating Lemna minor (L.) (Araceae) (Common duckweed), submerged Potamogeton epihydrus (Raf.) (Potamogetonaceae) (Ribbon-leaf pondweed), Nuphar variegeta (Durand.) (Nymphaeaceae) (Yellow pond-lily), and emerged Typha latifolia (L.) (Typhaceae) (Common cattail) in the removal of heavy metals in a mesocosm study. The study revealed that, amongst all macrophytes, floating macrophytes were more effective in assimilating heavy metals, followed by submerged, and lastly emergent macrophytes, which was similar to the present study.

Although there was promising heavy metal assimilation, the Swartkops River did not show overall water and habitat quality improvement downriver. This indicates that heavy metal reductions (>45\%) in concentration between native and non-native macrophyte stands did not improve the water and sediment quality contamination; however, this was not the same for some important sediments and macrophyte pollution indices, which were variable across sites.

This could be due to constant influxes from multiple non-point and point sources (i.e., sewage treatment works, industries, and other anthropogenic activities) along the river system, meaning that the constant inputs have a significant effect on the system deterioration. Distance between sampled sites could have also influenced our findings, as some sites were located about one kilometre away from the non-native macrophyte stands, thus, allowing pollution inputs between sites, further suppressing the assimilation as seen in this study.

In addition, field experiments are considered dynamic and difficult to work with because they are complex and are affected by multiple extraneous variables that are not easy to control and can affect the outcome of results. Since this study was the first of its kind in the highly impacted Swartkops River system, we show that the phytoremediation technique can be effective; however, the state and land-use pressure play a crucial role, and we recommend more field-based studies with limited alterations. 


\section{Conclusions}

The study showed the promising phytoremediation potential of native and non-native macrophytes to mitigate heavy metal contaminants from anthropogenic activities along the Swartkops River system. Water and sediment pollution indices were variable across sites showing no consistent trend in the reduction of water and sediment quality, and this was in contrast with our hypothesis. The lack of water and sediment quality improvement down river could have been due to constant pollution effluents from multiple non-point sources along the river system.

It is also possible that the river system could have been severely polluted to the extent that ecosystem services provided by both native and non-native macrophytes (although evident) were supressed. This study showed that native and non-native macrophytes can be used to assimilate pollutants; however, this can be better achieved in more control settings, i.e., laboratory and mesocosm settings, compared to complex and dynamic field conditions.

The screening of sediments and macrophytes (both native and non-native) provided an overview state of the Swartkops River system, and this may serve as an early warning or indication of changes in the system. Various authors $[14,16,23,30,31,40]$ have demonstrated phytoremediation success in the reduction of water and sediments heavy metal concentrations; however, very few studies have tested if the improvement of water and sediment quality assists the recovery of biological diversity particularly through biological indicators, i.e., aquatic macroinvertebrates.

Thus, we propose that adjunctive studies should be conducted to assess phytoremediation using biological variables (periphyton, aquatic macroinvertebrate, etc.) to quantify phytoremediation success. The current study further emphasizes that physicochemical variables are not sensitive but variable and can only provide a snap-shot of habitat degradation. The sediment and macrophyte indices were reliable indicators of heavy metal contamination and macrophyte bio-accumulation potential; however, excessive anthropogenic input in the Swartkops River suppressed macrophyte ecosystem services. We therefore recommend more field studies to test various green technologies to mitigate the deterioration water and habitat quality using relevant biological indicators.

Supplementary Materials: The following are available online at https: / www.mdpi.com/article/ 10.3390/plants10122676/s1, Table S1: A summary of bio-physical characteristics of the ten sampling sites at the Swartkops River system, Eastern Cape, South Africa. Table S2: Water chemistry mean values and \pm standard deviation recorded from 10 sites, including non-native macrophytes stands along the Swartkops River system South Africa from April-September 2018. Bolded $H$-values indicate significant differences (Kruskal-Wallis ANOVA, $p<0.05$ ); NS = not significant, $p>0.05$. Table S3: Sediment chemistry mean and ( \pm standard deviation) recorded from 10 sites, including native macrophytes stands along the Swartkops River system South Africa (April 2018-September 2018). Bolded $H$-values indicate significant differences (Kruskal-Wallis ANOVA, $p<0.05)$. Table S4: Percentage reduction of heavy metals concentration in sediments semi and permanent stands of Pontederia crassipes and Salvinia molesta along the Swartkops River system, Eastern Cape, South Africa.

Author Contributions: Conceptualization, G.T., S.N.M. \& M.P.H.; Data curation, G.T.; Formal analysis, G.T.; Funding acquisition, M.P.H.; Investigation, G.T., S.N.M. \& M.P.H.; Methodology, G.T. \& S.N.M.; Project administration, S.N.M. \& G.T.; Resources, S.N.M. \& M.P.H.; Software, G.T.; Supervision, S.N.M. \& M.P.H.; Validation, S.N.M. \& M.P.H.; Visualization, G.T., S.N.M. \& M.P.H.; Writing—original draft, G.T.; Writing—review \& editing, G.T., S.N.M. \& M.P.H. All authors have read and agreed to the published version of the manuscript.

Funding: NRF SARChI Chair: Grant number 84643.

Acknowledgments: This research was funded through the Department of Environmental Affairs, Natural Resource Management Programme, Working for Water Programme South Africa. Additional funding was provided by the South African Research Chairs Initiative of the Department of Science and Technology and the National Research Foundation of South Africa. Any opinion, finding, 
conclusion or recommendation expressed in this material is that of the authors, and not that of the National Research Foundation. We thank Lenin Chari, Takudzwa Comfort Madzivanzira, Aldwin Ndlovu, Tiyisani Chabalala, Zolile Maseko, Tshililo Mphephu, Evans Mauda, Bongiswa Ramalivhana, Frank Akamagwuna, Thifhelimbilu Mulateli, Nwabisa Magengelele, and Chumakwande Makehle for assistance during fieldwork.

Conflicts of Interest: The authors declare no conflict of interest.

Novelty Statement: Considering the alarming effects of anthropogenic activities on water quality and biodiversity in freshwater systems, our study assessed the assimilation potential of native and non-native macrophytes in a potentially toxic urban freshwater system through phytoremediation. This study is amongst the few studies that have tested phytoremediation in a field setting (in-situ), providing crucial information associated with quantifying phytoremediation in field settings. The findings from our study clearly showed the promising assimilation of both native and non-native macrophytes, and we strongly believe that our insights from this study will promote the use of macrophytes to mitigate pollution and restore riverine systems.

\section{References}

1. Motitsoe, S.N.; Hill, M.P.; Avery, T.S.; Hill, J.M. A new approach to the biological monitoring of freshwater systems: Mapping nutrient loading in two South African rivers, a case study. Water Res. 2020, 171, 115391. [CrossRef] [PubMed]

2. Kumar, S.; Deswal, S. Phytoremediation capabilities of Salvinia molesta, water hyacinth, water lettuce, and duckweed to reduce phosphorus in rice mill wastewater. Int. J. Phytoremediat. 2020, 22, 1097-1109. [CrossRef]

3. Geist, J.; Hawkins, S.J. Habitat recovery and restoration in aquatic ecosystems: Current progress and future challenges. Aquat. Conserv. Mar. Freshw. Ecosyst. 2016, 26, 942-962. [CrossRef]

4. Mishra, V.K.; Tripathi, B.D. Concurrent removal and accumulation of heavy metals by the three aquatic macrophytes. Bioresourse Technol. 2008, 99, 7091-7097. [CrossRef] [PubMed]

5. Yamada-Ferraz, T.M.; Sueitt, A.P.E.; Olivveira, A.F.; Botta, C.M.R.; Fadini, P.S.; Nascimento, M.R.L.; Faria, B.M.; Mozeto, A.A. Assessment of Phoslock ${ }^{\circledR}$ application in a tropical eutrophic reservoir: An integrated evaluation from laboratory to field experiments. Environ. Technol. Innov. 2015, 4, 194-205. [CrossRef]

6. Liu, D.M.; Chen, J.; Shi, Y.P. Advances on methods and easy separated support materials for enzymes immobilization. Trends Anal. Chem. 2018, 102, 332-342. [CrossRef]

7. Hanif, A.; Bhatti, H.N.; Hanif, M.A. Removal of zirconium from aqueous solution by Ganoderma lucidum: Biosorption and bioremediation studies. Desalination Water Treat. 2015, 53, 195-205. [CrossRef]

8. Karthika, N.; Jananee, K.; Murugaiyan, V. Remediation of contaminated soil using soil washing-a review. Int. J. Eng. Res. Appl. 2016, 1, 2248-9622.

9. Chandra, R.; Yadav, S. Potential of Typha angustifolia for phytoremediation of heavy metals from aqueous solution of phenol and melanoidin. Ecol. Eng. 2010, 36, 1277-1284. [CrossRef]

10. Šostar-Turk, S.; Petrinić, I.; Simonič, M. Laundry wastewater treatment using coagulation and membrane filtration. Resour. Conserv. Recycl. 2005, 44, 185-196. [CrossRef]

11. Sarma, H. Metal hyperaccumulation in plants: A review focusing on phytoremediation technology. Int. J. Environ. Sci. Technol. 2011, 4, 118-138. [CrossRef]

12. Ali, H.; Khan, E.; Sajad, M.A. Phytoremediation of heavy metals-concepts and applications. Chemosphere 2013, 91, 869-881. [CrossRef]

13. Mahar, A.; Wang, P.; Ali, A.; Awasthi, M.K.; Lahori, A.H.; Wang, Q.; Li, R.; Zhang, Z. Challenges and opportunities in the phytoremediation of heavy metals contaminated soils: A review. Ecotoxicol. Environ. Saf. 2016, 126, 111-121. [CrossRef]

14. Ali, S.; Abbas, Z.; Rizwan, M.; Zaheer, I.E.; Yavas, İ; Ünay, A.; Abdel-Daim, M.M.; Bin-Jumah, M.; Hasanuzzaman, M.; Kalderis, D. Application of floating aquatic plants in phytoremediation of heavy metals polluted water: A review. Sustainability 2020, 12, 1927. [CrossRef]

15. Hejna, M.; Moscatelli, A.; Stroppa, N.; Onelli, E.; Pilu, S.; Baldi, A.; Rossi, L. Bioaccumulation of heavy metals from wastewater through a Typha latifolia and Thelypteris palustris phytoremediationsystem. Chemosphere 2020, 241, 125018. [CrossRef] [PubMed]

16. Auchterlonie, J.; Eden, C.L.; Sheridan, C. The phytoremediation potential of water hyacinth: A case study from Hartbeespoort Dam, South Africa. S. Afr. J. Chem. Eng. 2021, 37, 31-36. [CrossRef]

17. Sakakibara, M.; Ohmori, Y.; Ha, N.T.H.; Sano, S.; Sera, K. Phytoremediation of heavy metal-contaminated water and sediment by Eleocharis acicularis. Clean-Soil Air Water 2011, 39, 735-741. [CrossRef]

18. Hua, J.; Zhang, C.; Yin, Y.; Chen, R.; Wang, X. Phytoremediation potential of three aquatic macrophytes in manganesecontaminated water. Water Environ. J. 2012, 26, 335-342. [CrossRef]

19. Mishra, V.K.; Tripathi, B.D. Accumulation of chromium and zinc from aqueous solutions using water hyacinth (Eichhornia crassipes). J. Hazard. Mater. 2009, 164, 1059-1063. [CrossRef] [PubMed]

20. Zhang, F.; Wang, X.; Yin, D.; Peng, B.; Tan, C.; Liu, Y.; Tan, X.; Wu, S. Efficiency and mechanisms of Cd removal from aqueous solution by biochar derived from water hyacinth (Eichhornia crassipes). J. Environ. Manag. 2015, 153, 68-73. [CrossRef] [PubMed] 
21. Bokhari, S.H.; Ahmad, I.; Mahmood-Ul-Hassan, M.; Mohammad, A. Phytoremediation potential of Lemna minor L. for heavy metals. Int. J. Phytoremediat. 2016, 18, 25-32. [CrossRef] [PubMed]

22. Mokhtar, H.; Morad, N.; Fizri, F.F.A. Phyto-accumulation of copper from aqueous solutions using Eichhornia crassipes and Centella asiatica. Int. J. Environ. Sci. Dev. 2011, 2, 205-210. [CrossRef]

23. Moyo, P.; Chapungu, L.; Mudzengi, B. Effectiveness of water hyacinth (Eichhornia crassipes) in remediating polluted water: The case of Shagashe River in Masvingo, Zimbabwe. Adv. Appl. Sci. Res. 2013, 4, 55-62.

24. Muthusaravanan, S.; Sivarajasekar, N.; Vivek, J.S.; Paramasivan, T.; Naushad, M.; Prakashmaran, J.; Gayathri, V.; AlDuaij, O.K. Phytoremediation of heavy metals: Mechanisms, methods and enhancements. Environ. Chem. Lett. 2018, 16, 1339-1359. [CrossRef]

25. Sheoran, V.; Sheoran, A.S.; Poonia, P. Role of hyperaccumulators in phytoextraction of metals from contaminated mining sites: A review. Crit. Rev. Environ. Sci. Technol. 2010, 41, 168-214. [CrossRef]

26. Basumatary, B.; Bordoloi, S.; Sarma, H.P. Crude oil-contaminated soil phytoremediation by using Cyperus brevifolius (Rottb.) Hassk. Water Air Soil Pollut. 2012, 223, 3373-3383. [CrossRef]

27. Hechmi, N.; Aissa, N.B.; Abdenaceur, H.; Jedidi, N. Evaluating the phytoremediation potential of Phragmites australis grown in pentachlorophenol and cadmium co-contaminated soils. Environ. Sci. Pollut. Res. 2014, 21, 1304-1313. [CrossRef]

28. Romanova, T.E.; Shuvaeva, O.V. Fractionation of mercury in water hyacinth and pondweed from contaminated area of gold mine tailing. Water Air Soil Pollut. 2016, 227, 171. [CrossRef]

29. Ng, Y.S.; Chan, D.J.C. Wastewater phytoremediation by Salvinia molesta. J. Water Process. Eng. 2017, 15, 107-115. [CrossRef]

30. Bello, A.O.; Tawabini, B.S.; Khalil, A.B.; Boland, C.R.; Saleh, T.A. Phytoremediation of cadmium-, lead-and nickel-contaminated water by Phragmites australis in hydroponic systems. Ecol. Eng. 2018, 120, 126-133. [CrossRef]

31. da Silva, A.A.; de Oliveira, J.A.; de Campos, F.V.; Ribeiro, C.; dos Santos Farnese, F.; Costa, A.C. Phytoremediation potential of Salvinia molesta for arsenite contaminated water: Role of antioxidant enzymes. Theor. Exp. Plant Physiol. 2018, 30, 275-286. [CrossRef]

32. Basumatary, B.; Saikia, R.; Das, C.H.; Bordoloi, S. Field note: Phytoremediation of petroleum sludge contaminated field using sedge species, Cyperus rotundus (Linn.) and Cyperus brevifolius (Rottb.). Int. J. Phytoremediat. 2013, 15, 877-888. [CrossRef]

33. Chayapan, P.; Kruatrachue, M.; Meetam, M.; Pokethitiyook, P. Phytoremediation potential of Cd and Zn by wetland plants, Colocasia esculenta L. Schott., Cyperus malaccensis Lam., and Typha angustifolia L. grown in hydroponics. J. Environ. Biol. 2015, $36,1179-1183$.

34. Cicero-Fernández, D.; Peña-Fernández, M.; Expósito-Camargo, J.A.; Antizar-Ladislao, B. Long-term (two annual cycles) phytoremediation of heavy metal-contaminated estuarine sediments by Phragmites australis. New Biotechnol. 2017, 38, 56-64. [CrossRef]

35. Shahid, M.J.; Ali, S.; Shabir, G.; Siddique, M.; Rizwan, M.; Seleiman, M.F.; Afzal, M. Comparing the performance of four macrophytes in bacterial assisted floating treatment wetlands for the removal of trace metals $(\mathrm{Fe}, \mathrm{Mn}, \mathrm{Ni}, \mathrm{Pb}$, and $\mathrm{Cr})$ from polluted river water. Chemosphere 2020, 243, 125353. [CrossRef]

36. Costanza, R.; De Groot, R.; Braat, L.; Kubiszewski, I.; Fioramonti, L.; Sutton, P.; Farber, S.; Grasso, M. Twenty years of ecosystem services: How far have we come and how far do we still need to go? Ecosyst. Serv. 2017, 28, 1-16. [CrossRef]

37. Alberti, M.; Booth, D.; Hill, K.; Coburn, B.; Avolio, C.; Coe, S.; Spirandelli, D. The impact of urban patterns on aquatic ecosystems: An empirical analysis in Puget lowland sub-basins. Landsc. Urban Plan. 2007, 80, 345-361. [CrossRef]

38. Loan, N.T.; Phuong, N.M.; Anh, N.T.N. The role of aquatic plants and microorganism in domestic wastewater treatment. Environ. Eng. Manag. J. 2014, 13, 2031-2038. [CrossRef]

39. Mishra, S.; Maiti, A. The efficiency of Eichhornia crassipes in the removal of organic and inorganic pollutants from wastewater: A review. Environ. Sci. Pollut. Res. 2017, 24, 7921-7937. [CrossRef] [PubMed]

40. Chiudioni, F.; Trabace, T.; Di Gennaro, S.; Palma, A.; Manes, F.; Mancini, L. Phytoremediation applications in natural condition and in mesocosm: The uptake of cadmium by Lemna minuta Kunth, a non-native species in Italian watercourses. Int. J. Phytoremediat. 2017, 19, 371-376. [CrossRef] [PubMed]

41. Ceschin, S.; Crescenzi, M.; Iannelli, M.A. Phytoremediation potential of the duckweeds Lemna minuta and Lemna minor to remove nutrients from treated waters. Environ. Sci. Pollut. Res. 2020, 27, 15806-15814. [CrossRef]

42. Kushwaha, A.; Hans, N.; Kumar, S.; Rani, R. A critical review on speciation, mobilization and toxicity of lead in soil-microbe-plant system and bioremediation strategies. Ecotoxicol. Environ. Saf. 2018, 147, 1035-1045. [CrossRef] [PubMed]

43. Coetzee, J.A.; Hill, M.P. The role of eutrophication in the biological control of water hyacinth, Eichhornia crassipes, in South Africa. BioControl 2012, 57, 247-261. [CrossRef]

44. Hess, M.C.; Mesléard, F.; Buisson, E. Priority effects: Emerging principles for invasive plant species management. Ecol. Eng. 2019, 127, 48-57. [CrossRef]

45. Tobias, V.D.; Conrad, J.L.; Mahardja, B.; Khanna, S. Impacts of water hyacinth treatment on water quality in a tidal estuarine environment. Biol. Invasions 2019, 21, 3479-3490. [CrossRef]

46. Coetzee, J.A.; Langa, S.D.F.; Motitsoe, S.N.; Hill, M.P. Biological control of water lettuce, Pistia stratiotes L., facilitates macroinvertebrate biodiversity recovery: A mesocosm study. Hydrobiologia 2020, 847, 3917-3929. [CrossRef]

47. Huizenga, J.M.; Silberbauer, M.; Dennis, R.; Dennis, I. An inorganic water chemistry dataset (1972-2011) of rivers, dams and lakes in South Africa. Water SA 2013, 39, 335-340. [CrossRef] 
48. Raggy Charters. Algoa Bay, Port Elizabeth. What We See-Marine Species in Port Elizabeth. Available online: https://www. raggycharters.co.za/filter/species/marine-species-in-algoa-bay-port-elizabeth (accessed on 14 May 2013).

49. Odume, O.N.; Muller, W.J.; Arimoro, F.O.; Palmer, C.G. The impact of water quality deterioration on macroinvertebrate communities in the Swartkops River, South Africa: A multimetric approach. Afr. J. Aquat. Sci. 2012, 37, 191-200. [CrossRef]

50. Muller, G. Index of geo-accumulation in sediments of the Rhine River. Geo-J. 1969, 2, 108-118.

51. Kumar, V.; Thakur, R.K. Pollution load of SIDCUL effluent with reference to heavy metals accumulated in sediments using pollution load index (PLI) and geo-accumulation index (Igeo) at Haridwar (Uttarakhand), India. J. Environ. Biosci. 2017, 31, 163-168.

52. Martin, J.M.; Meybeck, M. Elemental mass balance of materials carried by major world rivers. Mar. Chem. 1979, 7, 173-206. [CrossRef]

53. Muller, G. Die Schwermetallbelstung der sedimente des Neckars und seiner Nebenflusse: Eine Bestandsaufnahme. Chem. Ztg. 1981, 105, 157-164.

54. Islam, M.S.; Ahmed, M.K.; Habibullah-Al-Mamun, M.; Hoque, M.F. Preliminary assessment of heavy metal contamination in surface sediments from a river in Bangladesh. Environ. Earth Sci. 2015, 73, 1837-1848. [CrossRef]

55. Bubu, A.; Ononugbo, C.P.; Avwiri, G.O. Determination of heavy metal concentrations in sediment of Bonny River, Nigeria. Arch. Curr. Res. Int. 2017, 11, 1-11. [CrossRef]

56. Atgin, R.S.; El-Agha, O.; Zararsız, A.; Kocatas, A.; Parlak, H.; Tuncel, G. Investigation of the sediment pollution in Izmir Bay: Trace elements. Spectrochim. Acta Part B 2000, 55, 1151-1164. [CrossRef]

57. Chakravarty, I.M.; Patgiri, A.D. Metal Pollution Assessment in Sediments of the Dikrong River, N.E. India. J. Hum. Ecol. 2009, 27, 63-67. [CrossRef]

58. Tesfamariam, Z.; Younis, Y.M.H.; Elsanousi, S.S. Assessment of heavy metal status of sediment and water in Mainefhi and Toker drinking-water reservoirs of Asmara City, Eritrea. Am. J. Res. Commun. 2016, 4, 76-88.

59. Ganugapenta, S.; Nadimikeri, J.; Chinnapolla, S.R.R.B.; Ballari, L.; Madiga, R.; Nirmala, K.; Tella, L.P. Assessment of heavy metal pollution from the sediment of Tupilipalem Coast, southeast coast of India. Int. J. Sediment Res. 2018, 33, 294-302. [CrossRef]

60. Nirmala, K.; Ramesh, R.; Ambujam, N.K.; Arumugam, K.; Srinivasalu, S. Geochemistry of surface sediments of a tropical brackish water lake in South Asia. Environ. Earth Sci. 2016, 75, 1-11.

61. Chen, C.W.; Kao, C.M.; Chen, C.F.; Dong, C.D. Distribution and accumulation of heavy metals in the sediments of Kaohsiung Harbor, Taiwan. Chemosphere 2007, 66, 1431-1440. [CrossRef]

62. Buat-Menard, P.; Chesselet, R. Variable influence of the atmospheric flux on the trace metal chemistry of oceanic suspended matter. Earth Planet. Sci. Lett. 1979, 42, 399-411. [CrossRef]

63. Zayed, A.; Gowthaman, S.; Terry, N. Phyto-accumulation of trace elements by wetland plants: I. Duckweed. J. Environ. Qual. 1998, 27, 715-721. [CrossRef]

64. Mellem, J.J.; Baijnath, H.; Odhav, B. Bioaccumulation of $\mathrm{Cr}, \mathrm{Hg}$, As, $\mathrm{Pb}, \mathrm{Cu}$ and $\mathrm{Ni}$ with the ability for hyperaccumulation by Amaranthus dubius. Afr. J. Agric. Res. 2012, 7, 591-596.

65. R Core Team. R: A Language and Environment for Statistical Computing (Version 3.6.1) Vienna, Austria; R Foundation for Statistical Computing: Vienna, Australia, 2019. Available online: https:/ / www.R-project.org/ (accessed on 7 April 2019).

66. Hammad, D.M. Cu, Ni and Zn phytoremediation and translocation by water hyacinth plant at different aquatic environments. Aust. J. Basic Appl. Sci. 2011, 5, 11-22.

67. Wang, Z.; Zhang, Z.; Zhang, J.; Zhang, Y.; Liu, H.; Yan, S. Large-scale utilization of water hyacinth for nutrient removal in Lake Dianchi in China: The effects on the water quality, macrozoobenthos and zooplankton. Chemosphere 2012, 89, $1255-1261$. [CrossRef] [PubMed]

68. Eid, E.M.; Shaltout, K.H.; Moghanm, F.S.; Youssef, M.S.; El-Mohsnawy, E.; Haroun, S.A. Bioaccumulation and translocation of nine heavy metals by Eichhornia crassipes in Nile Delta, Egypt: Perspectives for phytoremediation. Int. J. Phytoremediat. 2019, 21, 821-830. [CrossRef]

69. Donatus, M. Removal of heavy metals from industrial effluent using Salvinia molesta. Int. J. Chemtech. Res. 2016, 9, 608-613.

70. Eid, E.M.; Shaltout, K.H.; El-Sheikh, M.A.; Asaeda, T. Seasonal courses of nutrients and heavy metals in water, sediment and above-and below-ground Typha domingensis biomass in Lake Burullus (Egypt): Perspectives for phytoremediation. Flora Morphol. Distrib. Funct. Ecol. Plants 2012, 207, 783-794. [CrossRef]

71. Binning, K.; Baird, D. Survey of heavy metals in the sediments of the Swartkops River Estuary, Port Elizabeth South Africa. Water SA 2001, 27, 461-466. [CrossRef]

72. Odume, O.N. An Evaluation of Macroinvertebrates-Based Biomonitoring and Ecotoxicological Assessments of Deteriorating Environmental Water Quality in the Swartkops River, South Africa. Ph.D. Thesis, Rhodes University, Makhanda, South Africa, 2014.

73. Adams, J.B.; Pretorius, L.; Snow, G.C. Deterioration in the water quality of an urbanised estuary with recommendations or improvement. Water SA 2019, 45, 86-96.

74. Jernström, J.; Lehto, J.; Dauvalter, V.A.; Hatakka, A.; Leskinen, A.; Paatero, J. Heavy metals in bottom sediments of Lake Umbozero in Murmansk Region, Russia. Environ. Monit. Assess. 2010, 161, 93-105. [CrossRef]

75. Hadad, H.R.M.; Maine, A.; Bonetto, C.A. Macrophyte growth in a pilot-scale constructed wetland for industrial wastewater treatment. Chemosphere 2006, 63, 1744-1753. [CrossRef] [PubMed] 
76. Schaller, J.; Vymazal, J.; Brackhage, C. Retention of resources (metals, metalloids and rare earth elements) by autochthonously/allochthonously dominated wetlands: A review. Ecol. Eng. 2013, 53, 106-114. [CrossRef]

77. Chandra, R.; Yadav, S. Phytoremediation of $\mathrm{Cd}, \mathrm{Cr}, \mathrm{Cu}, \mathrm{Mn}, \mathrm{Fe}, \mathrm{Ni}, \mathrm{Pb}$ and $\mathrm{Zn}$ from aqueous solution using Phragmites cummunis, Typha angustifolia and Cyperus esculentus. Int. J. Phytorem. 2011, 13, 580-591. [CrossRef]

78. Maric, M.; Antonijevic, M.; Alagic, S. The investigation of the possibility for using some wild and cultivated plants as hyperaccumulators of heavy metals from contaminated soil. Environ. Sci. Pollut. Res. 2013, 20, 1181-1188. [CrossRef]

79. Sharma, S.; Singh, B.; Manchanda, V.K. Phytoremediation: Role of terrestrial plants and aquatic macrophytes in the remediation of radionuclides and heavy metal contaminated soil and water. Environ. Sci. Pollut. Res. 2015, 22, 946-962. [CrossRef]

80. Vymazal, J.; Březinová, T. Accumulation of heavy metals in aboveground biomass of Phragmites australis in horizontal flow constructed wetlands for wastewater treatment: A review. Chem. Eng. J. 2016, 290, 232-242. [CrossRef]

81. Bonanno, G. Comparative performance of trace element bioaccumulation and biomonitoring in the plant species Typha domingensis, Phragmites australis and Arundo donax. Ecotoxicol. Environ. Saf. 2013, 97, 124-130. [CrossRef] [PubMed]

82. Goulet, R.R.; Lalonde, J.D.; Munger, C.; Dupuis, S.; Dumont-Frenette, G.; Prémont, S.; Campbell, P.G. Phytoremediation of effluents from aluminum smelters: A study of Al retention in mesocosms containing aquatic plants. Water Res. 2005, 39, 2291-2300. [CrossRef] 